\title{
DEFENDING ROLE OF RED GRAPE EXTRACT AGAINST NICOTINE INDUCED CHANGES OF CARBOHYDRATE METABOLISM IN THE SKELETAL MUSCLE TISSUES OF MALE ALBINO RAT WITH REFERENCE TO AGING
}

\author{
G.Sreenivasulu ${ }^{1}$, P.MuniLakshmi ${ }^{2}$, M.Jayachandrudu ${ }^{3}$, S. Kishore ${ }^{4}, K_{\text {K.Khalindar }}$ \\ Basha $^{5}$ and K. Chennaiah 6 . \\ 1,3,4,5,6 Department of Zoology, Sri Venkateswara University. Tirupati, Andhra Pradesh, India. \\ ${ }^{2}$ Department of Zoology, Sri Venkateswara Arts College (TTD), Tirupati, Andhra Pradesh, \\ India.
}

\section{ABSTRACT}

A grape (Vitis vinifera) is commercial juice product have been applied in medical research studies, showing potential benefits against the diseases. Nicotine, a major toxic component of cigarette smoking, has long been recognized to result in oxidative stress by inducing the generation of reactive oxygen species in the skeletal muscle tissue. Wistar strain male albino rats were used in the present study, rats were divided into 4 groups of six in each group i) Normal Control (NC) (Control rats received $0.9 \%$ saline) ; ii) Nicotine treated (Nt) (at a dose of $0.6 \mathrm{mg} / \mathrm{kg}$ body weight by subcutaneous injection for a period of 2 months ); iii) Red Grape extract treated (RGEt) (red grape extract $50 \mathrm{mg} / \mathrm{kg}$ body weight (after the standardization) via orogastric tube for a period of 2 months.); IV)) Nicotine + Red Grape (Nt+RGEt) (Rats were received the nicotine with a dose as mentioned in Group II and Group III. The animals were sacrificed after $48 \mathrm{hrs}$ after the last treatment by cervical dislocation and isolated the skeletal muscle tissues fiber types such as Gastrocnemeus (GN) and soleus (SOL) The levels of Total carbohydrates content, Glycogen, Total free aminoacids and Glycogenphosphorylases ( $\mathrm{a}$ and $\mathrm{ab}$ ) were decreed in nicotine treated rats in the skeletal muscle tissue and increased was observed in the combination treatment (Ni+RGEt) ratsof 50 $\mathrm{mg} / \mathrm{kg}$ body weight found more effective. This results stating that red grape extract treated rats are beneficial, especially for the nicotine subjects, and thereby to improve the health status and life span.

Keywords: Nicotine, Red Grape extract, Total carbohydrates, Glycogen, Total free aminoacids, Glycogenphosphorylases, skeletal muscles tissue and Male albino rat.

\section{Corresponding Author:}

Dr.K.Chennaiah

Assistant professor,

Department of Zoology,

Sri Venkateswara University, Tirupati,

Andhra Pradesh, India-517502.

E-mail: chennaiahk@gmail.com 


\section{INTRODUCTION}

Grape (Vitis vinifera L.) is one of the most commonly consumed fruit growing worldwide. The total amount about $80 \%$ is used in wine making (Maier et al., 2009) and the grape byproduct consists $20 \%$ of weight from winery process (Lafka et al., 2007). In Thailand, grape is usually processed into various products such as wine, juice and raisins. Black queen is one of the grape varieties that is normally processed into wine and juice and the large quantity of byproducts from both processes such as pomace (grape pulp, peels and seeds) were obtained and there has been several studies showing that these kind of by products could be a good source of antioxidants such as polyphenols and flavonoids. Wine is considered to be a high bioactive polyphenol content source. Many studies have revealed the key role played by phenolic compounds from grapes and wine on human health; cardiovascular diseases being the pathologies that have received much attention (Pozo-Bayón et al., 2012, Arranz et al., 2012). Wine is a widely consumed beverage in the world, with thousands of years of tradition. The phenolic compounds in grape berries are responsible for some of the major organoleptic properties of wine, such as color, astringency, bitterness, and aroma (Minussi et al., 2003; Pérez-Magariño and González-Sanjosé, 2006). During the red winemaking process, phenolic compounds from the skins of red grapes transfer to the must during the fermentation and any maceration steps (Salas et al., 2003). Based on their carbon skeleton, phenolic compounds are divided into two groups: flavonoid (anthocyanins, flavan3-ols, flavonols) and non-flavonoid compounds (hydroxybenzoic and hydroxycinnamic acids, stilbenes). Different types of phenolic compounds endow grape varieties and wines with specific quality characteristics.

Nicotine are highly addictive (Grana et al., 2014; Holbrook and Bradley, 2016). An average cigarette yields about $2 \mathrm{mg}$ of absorbed nicotine, and in lesser doses of that order, the substance acts as a stimulant in mammals, while high amounts $(50-100 \mathrm{mg}$ ) can be harmful (Mayer, 2014). This stimulant effect is a contributing factor to the addictive properties of tobacco smoking. Nicotine's addictive nature includes psychoactive effects, drug-reinforced behavior, compulsive use, relapse after abstinence, physical dependence and tolerance (Caponnetto et al., 2012). Nicotine is a natural ingredient acting as a botanical insecticide in tobacco leaves. It is the principal tobacco alkaloid, occurring to the extent of about $1.5 \%$ by weight in commercial cigarette tobacco and comprising about $95 \%$ of the total alkaloid content. Oral snuff and pipe tobacco contain concentrations of nicotine similar to cigarette tobacco, whereas cigar and chewing tobacco have only about half the nicotine concentration of cigarette tobacco. An average tobacco rod contains 10-14 mg of nicotine (Kozlowski et al., 1998), and on average about $1-1.5 \mathrm{mg}$ of nicotine is absorbed systemically during smoking (Benowitz and Jacob 1984). Nicotine in tobacco is largely the levorotary $(S)$-isomer; only $0.1-0.6 \%$ of total nicotine content is $(R)$-nicotine (Armstrong et al., 1998). Chemical reagents and pharmaceutical formulations of $(S)$-nicotine have a similar content of $(R)$ nicotine $(0.1-1.2 \%)$ as impurity since plant-derived nicotine is used for their manufacture. In most tobacco strains, nor nicotine and anatabine are the most abundant of minor alkaloids, followed by anabasine. This order of abundance is the same in cigarette tobacco and oral snuff, chewing, pipe, and cigar tobacco (Jacob et al., 1999). However, nornicotine levels are highest in cigar tobacco, anatabine levels are lowest in chewing tobacco and oral snuff, and anabasine levels are lowest in chewing tobacco (Jacob et al., 1999). Small amounts of the $N_{-}-$ methyl derivatives of anabasine and anatabine are found in tobacco and tobacco smoke. Several of the minor alkaloids are thought to arise by bacterial action or oxidation during tobacco processing rather than by biosynthetic processes in the living plant (Leete, 1983). These include myosmine, $N_{-}$-methylmyosmine, cotinine, nicotyrine, nornicotyrine, nicotine $N_{-}$-oxide, 2, 3_-bipyridyl, and metanicotine. Myosmine is found not only in tobacco but also 
in a variety of foods including nuts, cereals, milk, and potatoes (Tyroller et al., 2002). Also, nicotine is found in low levels in vegetables such as potatoes, tomatoes, and eggplants (Siegmund et al., 1999). Hence, this study was designed to investigate the effects of red grape extract and leaf extract on nicotine induced oxidative stress in the lung tissue of male albino rat.

The aging process has been shown to result in an accelerated functional decline. The exact mechanisms that cause this functional decline are unclear. The free radical theory of aging, however, has gained strong support because it is able to explain some of the processes that occur with aging and the degenerative diseases of aging. This theory proposes that an increase in oxygen radical production with age by mitochondria produce an increase in cellular damage (Harman, 1996, 1998). Aerobic organisms are well-protected against oxidative challenges by sophisticated antioxidant defense systems. However, it appears that during the aging process an imbalance between oxidants and antioxidants balance may occur, referred to as oxidative stress. Oxidative stress induced by oxidant species occurs under conditions when antioxidant defenses are depleted or when the rate constants of the radical reactions are greater than the antioxidant defense mechanisms (Buettner, 1993). Oxidative damage to these biomolecules seems to depend on hydrogen peroxide and a reduced transition metal. Therefore, molecules that contain transition metals, such as aconitase (a Krebs cycle enzyme), are likely to undergo oxidative damage (Hausladen and Fridovich, 1994). This study was designed to investigate the effects of Red grape extract on nicotine induced changes in carbohydrate metabolism in the skeletal muscle tissues of male albino rat with reference to aging.

\section{METERIALS AND METHODS}

\section{CARE AND MAINTENANCE OF EXPERIMENTAL ANIMALS:}

Male pathogenic free wistar albino rats were obtained from the Department of Zoology, Animal House, S.V. University,Tirupati, Andhra Pradesh, India. The animals were housed six to a polypropylene cage and provided with food and water add libitum. The animals were maintained under standard conditions of temperature and humidity with an alternating $12 \mathrm{hr}$ light/dark. The usage of animals was approved by the Institutional Animal Ethics Committee (Resolution No.10/(i)/a/CPCSEA/ IAEC/SVU/ZOOL/KC/ Dt.08.07.2012). Animals were fed standard pellet diet (Agro Corporation Pvt. Ltd., Bangalore, India) and maintained in accordance with the guidelines of the National Institute of Nutrition and Indian Council of Medical Research, Hyderabad, India.

\section{CHEMICALS:}

Nicotine and other fine chemical were obtained from Sigma chemical company, St. Louis, USA. All other chemicals and reagent used were of analytical grade.

\section{PREPARATION OF RED GRAPE EXTRACTION:}

Red Grapes, as large clusters with red berries, were brought from a local supermarket in Banglore and identified as Vitis vinifera L.(Family; Vitaceae) The grape were crushed (whole fruit) for juice and dried in shade, powdered and extract by maceration with $70 \%$ (W/V) alcoholic for $72 \mathrm{~h}$ in ambient temperature. The red grape extract was filtered and then solvent evaporated to dryness under reduced pressure in a rotary evaporator. The residual red grape extract was used for this study.

\section{EXPERIMENTAL DESIGN:}

Age matched rats ( Young and Old ) were divided into 4 groups of six in each groups. i) Normal Control, ii) Nicotine treatment (Nt),iii) Red Grape extracts treatment (RGEt) and, 
iv) Nicotine + Red Grape extract treatment (Nt+RGEt).Group I - Normal Control(NC), (Six rats were treated with normal saline $(0.9 \%)$ orally via orogastic tube for a period of 2 months).Group II - Nicotine treatment ( $\mathrm{Nt})$ (Rats were received the nicotine at a dose of 0.6 $\mathrm{mg} / \mathrm{kg}$ body weight $(0.5 \mathrm{ml})$ by subcutaneous injection for a period of 2 months).Group III Red Grape extract treatment (RGEt)(Rats were received red grape extract $50 \mathrm{mg} / \mathrm{kg}$ body weight via orogastric tube for a period of 2 months).Group IV - Nicotine + Red Grape extract treatment (Nt+RGEt) (Rats were received the nicotine at a dose of $0.6 \mathrm{mg} / \mathrm{kg}$ body weight $(0.5 \mathrm{ml})$ by subcutaneous injection and red grape extract $50 \mathrm{mg} / \mathrm{kg}$ body weight via orogastric tube for a period of 2 months).The animals were sacrificed after $48 \mathrm{hrs}$ after the last treatment session by cervical dislocation and the skeletal muscle fiber types tissue (GN and SOL) were isolated at $-4^{0}$, washed with ice-cold saline, immediately immersed in liquid nitrogen and stored at $-80^{\circ}$ for biochemical analysis and enzymatic assays. Before assay, the tissues were thawed, sliced and homogenized under ice-cold conditions. Selected parameters were estimated by employing standard methods.

\section{BIOCHEMICAL INVESTIGATIONS}

\section{TOTAL CARBOHYDRATES:}

The total carbohydrate content was estimated by the method of Carroll et al.,(1956).The skeletal muscle tissues (GN and SOL) were homogenized in 10\% trichloro acetic acid to prepare $1 \%(\mathrm{~W} / \mathrm{V})$ homogenates. The proteins precipitated were removed by centrifuging the homogenates for 15 minutes at $3000 \mathrm{~g}$ at $4^{0} \mathrm{C}$. The clear supernatant was taken for the estimation of total carbohydrates. To $0.5 \mathrm{ml}$ of supernatant, $5 \mathrm{ml}$ of anthrone reagent was added and kept in a boiling water bath for 15 minutes. Then, the contents were cooled and read at $620 \mathrm{~nm}$ against the reagent blank. The total carbohydrate content was expressed as mg of glucose/gm wet weight of the tissue.

\section{GLYCOGEN:}

The Glycogen was estimated by the method of Kemp and Van Hejnigen (1954). The tissues were homogenized in $80 \%(\mathrm{~W} / \mathrm{V})$ methanol to prepare $5 \%(\mathrm{~W} / \mathrm{V})$ homogenates. The suspension was centrifuged at $3000 \mathrm{~g}$ for 15 minutes at $4^{0} \mathrm{C}$ the supernatant containing glucose was decanted. (The glycogen content present in the skeletal muscle tissue homogenates was estimated after extraction of the glucose with $80 \%$ methanol). Now the tissue residue was suspended in $5 \mathrm{ml}$ of deproteinizing solutions (5\% TCA containing $0.1 \%$ silver sulphate) and the fluid level was marked on centrifuge tube and the tube was covered with a glass cap and placed in a boiling water bath for 15 minutes. Then the tube was cooled in running tap water and deproteinizing solution was added up to the mark to compensate the loss due to evaporation. The contents were centrifuged at $5000 \mathrm{~g}$ for 15 minutes at $4^{0} \mathrm{C} .1 \mathrm{ml}$ of clear supernatant was added to $3 \mathrm{ml}$ of concentrated sulphuric acid (AR) in a wide mouthed test tube mixed by vigorous shaking. The mixture was heated in a boiling water bath for exactly 6.5 minutes and subsequently cooled under running tap water. The intensity of the pink colour developed was read against the blank at $520 \mathrm{~nm}$ in a spectrophotometer. The glycogen content was expressed in $\mathrm{mg}$ glucose/gram wet weight of the tissue.

\section{TOTAL FREE AMINO ACIDS:}

The total free amino acids were estimated by the method of Moore and Stein (1954). $5 \%(\mathrm{~W} / \mathrm{V})$ homogenates of the tissues were prepared in $10 \%(\mathrm{~W} / \mathrm{V})$ trichloro acetic acid (TCA) and centrifuged the contents at $2000 \mathrm{~g}$ for $15 \mathrm{~min}$ at $4^{0} \mathrm{C}$. To $0.5 \mathrm{ml}$ of supernatant, $2.0 \mathrm{ml}$ of Ninhydrin reagent was added and the contents were exactly boiled for $61 / 2$ minutes in a boiling water bath. The contents were cooled to laboratory temperature. The samples were made upto $10 \mathrm{ml}$ with distilled water and the colour intensity was read at $570 \mathrm{~nm}$ in a 
spectrophotometer against the reagent blank. The total free amino acid content was expressed in $\mathrm{mg}$ of free amino acids per gram wet weight of the tissue.

\section{GLYCOGEN PHOSHORYLASE 'a' (active) and 'ab' (total) : (1,4- $\alpha$-D-glucon:} orthophosphate- $\alpha$-D-glucosyl transferase: E.C:2.4.1.1):

Phosphorylase activity in the muscles was estimated by the method of Cori et al.,(1955) in the direction of glycogen synthesis by determination of the amount of inorganic phosphate formed from glucose-1-phosphate, $5 \%$ (W/V) muscle homogenates were prepared in an aqueous medium containing sodium fluoride $(0.1 \mathrm{M})$ and ethylene diamine tetra acetic acid (EDTA) (0.037M) of pH 6.5 as recommended by Guillory and Mommaerts (1962) to avoid enzymatic interconversion of the two phosphorylases. The homogenates were centrifuged for 15 minutes at $1000 \mathrm{~g}$ at $4^{0} \mathrm{C}$ and the supernatant was diluted 4 times with cysteine $(0.03 \mathrm{M})$ - glycerophosphate $(0.015 \mathrm{M})$ buffer at $\mathrm{pH} 6.5 .0 .4 \mathrm{ml}$ of diluted enzyme (corresponding to $20 \mathrm{mg}$ of muscle) was added to $0.2 \mathrm{ml}$ of $2 \%$ glycogen and incubated for 20 minutes at $37^{\circ} \mathrm{C}$. The reaction was started by the addition of $0.2 \mathrm{ml}$ of glucose-1phosphate $(0.016 \mathrm{M})$ to one of the tubes and to the other $0.2 \mathrm{ml}$ of glucose-1-phosphate $(0.016 \mathrm{M})$ containing adenosine-5-monophosphate (AMP) $(0.004 \mathrm{M})$ for estimating active phosphorylase (a) and total phosphorylase (ab) respectively. After incubating the reaction mixture for 15 minutes for total phosphorylase and 30 minutes for active phosphorylase, the reaction was arrested by the addition of $1 \mathrm{ml}$ of $10 \%$ TCA and centrifuged. The inorganic phosphate formed was estimated by the method of Fiske and Subba Row (1925). To the supernatant, $1 \mathrm{ml}$ of molybdate reagent was added followed by the addition of $0.4 \mathrm{ml}$ of aminonaphtho-sulphonic acid (ANSA) reagent. The contents were diluted to $10 \mathrm{ml}$ with distilled water. The colour developed was read immediately at $660 \mathrm{~nm}$ in a spectrophotometer against the reagent blank. Phosphorylase activity was expressed as $\mu$ moles of inorganic phosphate liberated/mg protein/hour.

\section{PROTEIN ASSAY}

Protein content where ever mentioned was estimated by the method of Lowry et al., (1951) using bovine serum albumin as standard.

\section{STATISTICAL ANALYSIS}

Statistical analysis has been carried out using INSTAT software. The data was analyzed for the significance; the results were presented with the P-values.

\section{TOTAL CARBOHYDRATES RESULTS :}

In the present study in total carbohydrates content was increased in both (young and old) RGEt rats of GN (young by $+1.26 \%$; old by $+4.68 \%$ ) and SOL( Young by $+8.46 \%$; Old by $+14.79 \%$ ) when compared to control rats. In Nicotine treated rats the decrease was observed in both the tissues of GN (young by -0.12 ; Old by $-2.25 \%$ ) and SOL (Young by 5.67; Old by $-2.74 \%$ ). than the control rats, In the combination treatment (Nt+RGEt) slightly increase was observed when compared to control rats of both age groups in the both tissues. (Table.1) 
Table-1: Changes in Total Carbohydrates content due to Red Grape Extract treatment (RGEt), Nicotine treatment (Nt) and interaction of the both (RGEt+Nt) for a period of 2 months over the control in Gastrocnemius (GN) and Soleus (SOL) muscles of male albino rats of young (3 months) and old (18 months) age groups. Values are expressed in $\mathrm{mg} / \mathrm{gram}$ wet weight of the tissue.

\begin{tabular}{|c|c|c|c|c|c|c|c|c|c|}
\hline \multirow{2}{*}{$\begin{array}{l}\text { S. } \\
\text { No }\end{array}$} & \multirow{2}{*}{$\begin{array}{l}\text { Name } \\
\text { of the } \\
\text { tissue }\end{array}$} & \multicolumn{4}{|c|}{ Young } & \multicolumn{4}{|c|}{ Old } \\
\hline & & Control & RGEt & $\mathrm{Nt}$ & $\mathrm{RGEt}+\mathrm{Nt}$ & Control & RGEt & $\mathrm{Nt}$ & $\mathrm{RGEt}+\mathrm{Nt}$ \\
\hline 1 & GN & $\begin{array}{c}252.03 \\
\pm 4.96\end{array}$ & $\begin{array}{c}255.21 \\
\pm 4.27 \\
(+1.26)\end{array}$ & $\begin{array}{c}251.72 \\
\pm 2.47 \\
(-0.12)\end{array}$ & $\begin{array}{c}259.04 \\
\pm 3.83 \\
(+2.78)\end{array}$ & $\begin{array}{c}256.25 \\
\pm 4.97\end{array}$ & $\begin{array}{c}268.26 \\
\pm 3.83 \\
(+4.68)\end{array}$ & $\begin{array}{c}250.47 \\
\pm 3.93 \\
(-2.25)\end{array}$ & $\begin{array}{c}263.93 \\
\pm 3.22 \\
(+2.99)\end{array}$ \\
\hline 2 & SOL & $\begin{array}{c}233.76 \\
\pm 3.83\end{array}$ & $\begin{array}{c}253.54 \\
\pm 4.11 \\
(+8.46) \\
\end{array}$ & $\begin{array}{c}220.49 \\
\pm 4.37 \\
(-5.67)\end{array}$ & $\begin{array}{c}250.68 \\
\pm 3.25 \\
(+7.23)\end{array}$ & $\begin{array}{c}238.33 \\
\pm 5.58\end{array}$ & $\begin{array}{c}273.58 \\
\pm 4.32 \\
(+14.79)\end{array}$ & $\begin{array}{c}231.79 \\
\pm 3.85 \\
(-2.74) \\
\end{array}$ & $\begin{array}{c}258.10 \\
\pm 3.51 \\
(+8.29)\end{array}$ \\
\hline
\end{tabular}

All the values are \pm SD of six individual observations.

Values in parentheses denote per cent change over respective sedentary control.

* Values are significant at $\mathrm{P}<0.001$

** Values are significant at $\mathrm{P}<0.05$

@ Values are non-significant.

\section{GLYCOGEN:}

In the present study in total carbohydrates content was increased in both (young and old) RGEt rats of GN (young by $+16.63 \%$; old by $+14.65 \%$ ) and SOL( Young by $+13.96 \%$; Old by $+37.58 \%$ ) when compared to control rats. In Nicotine treated rats the decrease was observed in both the tissues of GN (young by -19.60 ; Old by $-29.74 \%$ ) and SOL (Young by -22.63 ; Old by $-31.99 \%$ ). than the control rats, In the combination treatment (Nt+RGEt) slightly increase was observed when compared to control rats of both age groups in the both tissues. (Table.2).

Table-2: Changes in Glycogen content due to Red Grape Extract treatment (RGEt), Nicotine treatment $(\mathrm{Nt})$ and interaction of the both $(\mathrm{RGEt}+\mathrm{Nt})$ for a period of 2 months over the control in Gastrocnemius (GN) and Soleus (SOL) muscles of male albino rats of young (3 months) and old (18 months) age groups. Values are expressed in $\mathrm{mg} / \mathrm{gram}$ wet weight of the tissue.

\begin{tabular}{|c|c|c|c|c|c|c|c|c|c|}
\hline \multirow{2}{*}{$\begin{array}{l}\text { S. } \\
\text { No }\end{array}$} & \multirow{2}{*}{$\begin{array}{l}\text { Name } \\
\text { of the } \\
\text { tissue }\end{array}$} & \multicolumn{4}{|c|}{ Young } & \multicolumn{4}{|c|}{ Old } \\
\hline & & Control & RGEt & $\mathrm{Nt}$ & $\mathrm{RGEt}+\mathrm{Nt}$ & $\begin{array}{c}\text { Contro } \\
1\end{array}$ & RGEt & $\mathrm{Nt}$ & $\mathrm{RGEt}+\mathrm{Nt}$ \\
\hline 1 & GN & $\begin{array}{c}5.05 \\
\pm 0.85\end{array}$ & $\begin{array}{c}5.89^{@} \\
\pm 1.28 \\
(+16.63)\end{array}$ & $\begin{array}{c}4.06 \\
\pm 1.43 \\
(-19.60)\end{array}$ & $\begin{array}{c}11.28^{*} \\
\pm 1.46 \\
(+123.36)\end{array}$ & $\begin{array}{c}4.64 \\
\pm 1.39\end{array}$ & $\begin{array}{c}5.32^{@} \\
\pm 1.63 \\
(+14.65)\end{array}$ & $\begin{array}{c}3.26 \\
\pm 1.30 \\
(-29.74)\end{array}$ & $\begin{array}{c}7.06^{*} \\
\pm 1.63 \\
(+52.15)\end{array}$ \\
\hline 2 & SOL & $\begin{array}{c}6.23 \\
\pm 1.39\end{array}$ & $\begin{array}{c}7.10^{@} \\
\pm 1.52 \\
(+13.96)\end{array}$ & $\begin{array}{c}4.82 * \\
\pm 1.64 \\
(-22.63)\end{array}$ & $\begin{array}{c}8.26^{@} \\
\pm 2.13 \\
(+32.58)\end{array}$ & $\begin{array}{c}5.72 \\
\pm 1.50\end{array}$ & $\begin{array}{c}7.87 * \\
\pm 1.62 \\
(+37.58)\end{array}$ & $\begin{array}{c}3.89 * * \\
\pm 1.35 \\
(-31.99)\end{array}$ & $\begin{array}{c}7.10^{@} \\
\pm 1.92 \\
(+24.12)\end{array}$ \\
\hline
\end{tabular}


All the values are \pm SD of six individual observations.

Values in parentheses denote per cent change over respective sedentary control.

* Values are significant at $\mathrm{P}<0.001$

** Values are significant at $\mathrm{P}<0.05$

@ Values are non significant.

\section{TOTAL FREE AMINOACIDS:}

In the present study in total carbohydrates content was increased in both (young and old) RGEt rats of GN (young by $+41.85 \%$; old by $+41.18 \%$ ) and SOL( Young by +90.39\%; Old by $+5.33 \%$ ) when compared to control rats. In Nicotine treated rats the decrease was observed in both the tissues of GN (young by -44.98 ; Old by $-11.28 \%$ ) and SOL (Young by -3.24 ; Old by $-8.12 \%$ ). than the control rats, In the combination treatment (Nt+RGEt) slightly increase was observed when compared to control rats of both age groups in the both tissues. (Table.3).

Table -3: Changes in Total free amino acids activity due to Red Grape Extract treatment (RGEt), Nicotine treatment (Nt) and interaction of the both (RGEt+Nt) for a period of 2 months over the control in Gastrocnemius (GN) and Soleus (SOL) muscles of male albino rats of young (3 months) and old (18 months) age groups. Values are expressed in $\mathrm{mg} / \mathrm{gram}$ wet weight of the tissue.

\begin{tabular}{|c|c|c|c|c|c|c|c|c|c|}
\hline \multirow{2}{*}{ S.No } & \multirow{2}{*}{$\begin{array}{l}\text { Name of } \\
\text { the tissue }\end{array}$} & \multicolumn{4}{|c|}{ Young } & \multicolumn{4}{|c|}{ Old } \\
\hline & & Control & RGEt & $\mathrm{Nt}$ & $\mathrm{RGEt}+\mathrm{Nt}$ & Control & RGEt & $\mathrm{Nt}$ & $\mathrm{RGEt}+\mathrm{Nt}$ \\
\hline 1 & GN & $\begin{array}{l}20.43 \\
\pm 1.49\end{array}$ & $\begin{array}{c}11.88 * \\
\pm 1.45 \\
(+41.85)\end{array}$ & $\begin{array}{c}11.24^{*} \\
\pm 1.57 \\
(-44.98)\end{array}$ & $\begin{array}{c}16.45^{*} \\
\pm 2.16 \\
(-19.48)\end{array}$ & $\begin{array}{l}10.10 \\
\pm 1.68\end{array}$ & $\begin{array}{c}14.26^{*} \\
\pm 1.74 \\
(+41.18)\end{array}$ & $\begin{array}{c}8.96 * * \\
\pm 1.38 \\
(-11.28)\end{array}$ & $\begin{array}{c}14.64 * \\
\pm 1.68 \\
(+44.95)\end{array}$ \\
\hline 2 & SOL & $\begin{array}{c}8.64 \\
\pm 1.31\end{array}$ & $\begin{array}{c}16.45^{*} \\
\pm 1.37 \\
(+90.39)\end{array}$ & $\begin{array}{l}8.36^{@} \\
\pm 2.52 \\
(-3.24)\end{array}$ & $\begin{array}{c}10.92 * * \\
\pm 1.96 \\
(+26.38)\end{array}$ & $\begin{array}{c}8.62 \\
\pm 1.79\end{array}$ & $\begin{array}{c}9.08^{@} \\
\pm 1.46 \\
(+5.33)\end{array}$ & $\begin{array}{c}7.92^{@} \\
\pm 2.33 \\
(-8.12)\end{array}$ & $\begin{array}{c}9.43^{@} \\
\pm 1.47 \\
(+9.39)\end{array}$ \\
\hline
\end{tabular}

All the values are \pm SD of six individual observations.

Values in parentheses denote per cent change over respective sedentary control.

* Values are significant at $\mathrm{P}<0.001$

** Values are significant at $\mathrm{P}<0.05$

@ Values are non-significant.

\section{GLYCOGEN PHOSPHORYLASES :}

In the present study in total carbohydrates content was increased in both (young and old) RGEt rats of GN (young by $+6.05 \%$; old by $+2.95 \%$ ) and SOL( Young by $+8.93 \%$; Old by $+2.77 \%$ ) when compared to control rats. In Nicotine treated rats the decrease was observed in both the tissues of GN (young by -10.63 ; Old by $-12.93 \%$ ) and SOL (Young by -14.10 ; Old by $-23.06 \%$ ). than the control rats, In the combination treatment (Nt+RGEt) slightly increase was observed when compared to control rats of both age groups in the both tissues (Table.4). 
Table - 4: Changes in Glycogen Phosphorylase-a activity due to Red Grape Extract treatment (RGEt), Nicotine treatment $(\mathrm{Nt})$ and interaction of the both (RGEt+Nt) for a period of 2 months over the Sedentary Control (SC) in Gastrocnemius (GN) and Soleus (SOL) muscles of male albino rats of young (3 months) and old (18 months) age groups. Values are expressed as $\mu$ moles of inorganic phosphate liberated/mg protein/hour.

\begin{tabular}{|c|c|c|c|c|c|c|c|c|c|}
\hline \multirow{2}{*}{$\begin{array}{l}\text { S. } \\
\text { No }\end{array}$} & \multirow{2}{*}{$\begin{array}{l}\text { Name of } \\
\text { the tissue }\end{array}$} & \multicolumn{4}{|c|}{ Young } & \multicolumn{4}{|c|}{ Old } \\
\hline & & Control & RGEt & $\mathrm{Nt}$ & $\mathrm{RGEt}+\mathrm{Nt}$ & Control & RGEt & $\mathrm{Nt}$ & $\mathrm{RGEt}+\mathrm{Nt}$ \\
\hline 1 & GN & $\begin{array}{l}45.41 \\
\pm 1.87\end{array}$ & $\begin{array}{c}48.16^{@} \\
\pm 2.88 \\
(+6.05)\end{array}$ & $\begin{array}{c}40.58 * * \\
\pm 2.23 \\
(-10.63)\end{array}$ & $\begin{array}{c}43.62^{@} \\
\pm 1.91 \\
(-3.94)\end{array}$ & $\begin{array}{l}43.36 \\
\pm 2.74\end{array}$ & $\begin{array}{c}44.64^{@} \\
\pm 2.83 \\
(+2.95)\end{array}$ & $\begin{array}{c}37.75^{*} \\
\pm 2.00 \\
(-12.93)\end{array}$ & $\begin{array}{c}39.79 * \\
\pm 1.91 \\
(-8.23)\end{array}$ \\
\hline 2 & SOL & $\begin{array}{l}57.72 \\
\pm 1.92\end{array}$ & $\begin{array}{c}62.88 * * \\
\pm 3.29 \\
(+8.93)\end{array}$ & $\begin{array}{c}49.58 * \\
\pm 1.87 \\
(-14.10)\end{array}$ & $\begin{array}{c}52.59 * * \\
\pm 1.74 \\
(-8.88)\end{array}$ & $\begin{array}{l}45.44 \\
\pm 4.02\end{array}$ & $\begin{array}{c}46.70^{@} \\
\pm 2.69 \\
(+2.77)\end{array}$ & $\begin{array}{c}34.96 * \\
\pm 3.45 \\
(-23.06)\end{array}$ & $\begin{array}{c}44.33^{@} \\
\pm 4.73 \\
(-2.44)\end{array}$ \\
\hline
\end{tabular}

All the values are \pm SD of six individual observations.

Values in parentheses denote per cent change over respective sedentary control.

* Values are significant at $\mathrm{P}<0.001$

** Values are significant at $\mathrm{P}<0.05$

@ Values are non significant.

\section{RESULTS AND DISCUSSION :}

A contracting muscle has a demand for an extra energy and the ability to maintain energy and redox status varies considerably among different muscle types (Essen et al.,1980; Garcia - Esteller et al., 1982; Hintz et al.,1982; Idstrom et al.,1985; Venkataiah, 1995). In the present investigation it was observed that the aging results in the slight elevation in total carbohydrates in both gastrocnemius and soleus muscles which may be due to decreased metabolic utilization in the old animals. The impaired alterations in the activities of enzymes involved in the carbohydrate metabolism contribute to the reduction of carbohydrate catabolism and elevation in age-related accumulation of tissue carbohydrates. The agerelated slowing down and impairment in carbohydrate metabolism appears to play a role in the expression of cellular senescence (Tollefsbol, 1987).

The significant decrease in total carbohydrate levels in the selected skeletal muscles (GN and SOL) of old rats after nicotine treatment suggest possible utilization of carbohydrates to meet the energy demand during ethanol toxicity. Similar pattern of changes in carbohydrate levels has been reported in brain and other tissues of rats during ethanol intoxication. This is possible due to the products of nicotine metabolism that inhibit the formation of glucose from other compounds such as aminoacids etc. These findings support the present results that the utilization of carbohydrates is more in older rats than the young ones (Table.1). Young rats can more readily maintain high levels of oxygen consumption accompanied by a more efficient use of fats as an energy source compared to old ones (Somani et al.,1992; The Hindu, Science and Technology, "Hot Line" April 10, 1997). Holloszy and Booth (1976) observed that during endurance training skeletal muscle adapt to slower utilization of carbohydrate and increased reliance on fat oxidation as a source of energy. In the present study the combination treatment significantly enhanced the total 
carbohydrates content in both the muscle fibres, suggesting the beneficial effect of red grape extract under induced nicotine conditions.

Glycogen levels were increased in GN, SOL of both the age groups after two months red grape extract due to increased glycogenesis or gluconeogenesis (Cartee, 1994; Hughes, 1995; Dhahbi et al.,1999) to meet the energy demands of the tissue. In the present investigation it was observed that the glycogen content was more in SOL than the GN of red grape extract rats, which may be attributed to functional adaptations of the fibres. Red grape extract also alters the sensitivity of tissues like muscles to catecholamines and shifts the fuel substrate to fat (Holloszy and Booth, 1976; Trueth et al., 1995). Hence, glycogen utilization is reduced resulting in its accumulation. The increase in the glycogen content may be due to decreased utilization of glycogen for energy release, since fats are preferred over carbohydrates or it may be due to increased synthesis of same from non-carbohydrate sources or both.

The elevation in the skeletal muscle glycogen concentration also accounts from the decrease in blood glucose during endurance exercise (Bilwanath, 1996). Glycogenolysis in muscle is inhibited by increased accumulation of glucose-6-phosphate resulted due to increased permeability of muscle to glucose, induced by training (Tarnopolsky et al.,1995). The elevated levels of glycogen in the muscle fiber types may also suggest possible augmentation of turnover rate of carbohydrates during endurance exercise (Asha Devi and Bhagavathi, 1993) and reflect the differences in the endurance capacities between them. The excess glucose entered into the muscle may be converted to stored carbohydrates thereby resulting in increased glycogen content in the red grape extract muscles. These changes in muscle glucose and glycogen may be due to possible physiological or functional adaptations to endurance red grape extract.

From the present investigation it was observed that the muscle glycogen levels significantly decreased (Table.2) due to aging. The decrease in the glycogen content with advancement of age may be due to augmented glycogen degradation, through glycolysis or due to decreased synthesis of glycogen during aging. Takahashi et al.,(1970) reported reduction in glycogen levels with advancement of age. The decrease in glycogen (Drahota and Gutmann, 1963), ATP (Ermini and Verzar, 1968; Frubel Osipova, 1969), ATP/ADP ratio (Ermini et al., 1971) and Creatine phosphate (Ermini, 1970) reflects a deficiency in energetics of muscular contraction in old age. The decreased mitochondrial oxidation as revealed by decreased activity of Glycogen levels clearly indicates the prevalence of hypoxic conditions in the tissues, which normally increases glycogen utilization.

Peters et al.,(1996) reported that nicotine, and its byproducts were associated with reduced glycogen resynthesis in skeletal muscles. Chronic nicotine intake produced an increase in glycogen concentration and decrease in pyruvate kinase activity before the first signs of myopathy appeared. When myopathy was present, glycogen decreased. These changes may contribute to the decline in skeletal muscle performance in myopathy cases (Vernet et al.,1995). Reduced levels of glycogen also could lead to reduced glucose availability and glycolysis in cells. Studies of the intact liver (Van Horn et al.,2001), whole liver hepatocytes (Van Horn and Cunningham, 1999; Van Horn et al.,2001) and periportal and perivenous hepatocytes (Baio et al.,1998) demonstrated that glycogen levels are greatly reduced in livers of chromic alcohol consumers. Similarly, in skeletal muscle fibers the reduced glycogen levels may be attributed to reduced glucose availability and glycolysis. Both the muscle fibers showed similar trend of changes in glycogen content under experimental conditions, which reveals no specific fiber type alterations in the glycogen content in GN and SOL muscle fibers. 
The total FAA content increased significantly in both skeletal muscles due to red rape extract. Similar increase in the amino acid levels during muscular work was reported in the muscle of frog (Rajendra et al.,1980; Bhargava, 1982), rat (Dohm et al.,1981; Krishna Mohan et al.,1985b) and plasma of human subjects (Pivarnik et al.,1984). The total FAAs in skeletal muscles arise from a balance between a numbers of factors. Amino acids are added to the pool through the synthesis of non-essential amino acids and precursors within the tissue and through release of amino acids from the breakdown of dietary and cellular proteins in the tissues. Muscle provides much larger portions of the total FAA pool of the body than does liver (Nelsons and Cox, 2000). The total amino acid turnover per hour is also much greater for muscle than for liver.

The increased amino acid content in the red rape extract muscles may be due to augmented activity of acidic, alkaline and neutral proteases. This elevation in amino acid level may also be attributed to the enhanced proteolysis as well as decreased amino acid utilization for protein synthesis (Bylund-Fellenius et al.,1984). Perhaps, the elevated pool of FAA in the red rape extract muscles may serve as an important source for the increased energy expenditure through their oxidation. Sahlin et al.,(1978) demonstrated that acceleration of proteolytic enzymes was proportional to the increased acidity in red rape extract muscle.

Besides these, the enhanced level of FAA may be due to ammonia intoxication (Krishna Mohan Reddy, 1986). In this present study it is reported that total free amino acids content was decreased due to ethanol treatment in both age groups. This decrease may be due to the effect of nicotine products on the FAA content in the plasma. Similar reports are available under acute ethanol administration condition (Mila Kofsky et al.,1986). It was observed the concentration of ethanol load may influence the aminoacid pool (Green et al.,1981). However, contradictory reports are also available regarding the influence of nicotine on total free aminoacid pool. The low levels of FAA in the muscle fibers due tonicotine treatment may also be due to high utilization of these to carbohydrate sources via gluconeogenesis pathway to meet the energy demand under the influence of nicotine intoxication. In the present study we observed an elevation of FAA pool in the muscle fibers due to combination of red grape extract and nicotine, suggests the red grape extract training enhances the supply of FAA content to counter the nicotine toxicity. This is more observed in old age groups than in young muscle fibers.

Phosphorylase system was found to be inactivated by the accumulation of organic acids (Chandra Sekharam Naidu, 1973; Reddanna 1979, Bhargava, 1982; Chasiotis, 1983; Uma Devi, 1992). Accumulation of lactic acid may be responsible for decrease in phosphorylase activity in muscles (Bhargava, 1982; Chasiotis et al.,1982). Since lactic acid levels were found to increase during aging, in the present investigation the phosphorylase inhibition was also greater in the skeletal muscles of old rats. Further the activity of phosphorylase is known to depend on the availability of inorganic phosphate.

The elevated levels of phosphorylase activity in both the skeletal muscles of rats after acute red grape extract indicate the mobilization of glycogen reserves to glucose-1-phosphate to provide energy in order to meet the energy demands during endurance red grape extract. But in the present investigation despite increased utilization, glycogen content was found to increase in the muscles of red grape extract rats indicating higher rate of operation of gluconeogenesis or glycogenesis than glycogenolysis and also transport of glucose from other organs by permeability of muscle to glucose after exercise (Coggan et al.,1995). Among the muscles studied the red grape extract induced elevation in phosphorylases was more in GN of young rats than in old rats when compared to SOL. 
A decrease in the phosphorylase system has been observed due to nicotine treatment and combination effect. This may be due to the accumulation of lactic acid in blood and muscle fibres and also it may be due to elevation in basic protein levels in the muscle fibres (Padmavathi et al.,1975). Similar studies in different toxicant the decreased activities of phosphorylases due to ethanol intoxication may be due to degradation of muscle protein as a result of elevated protease activity as observed by Krishnamohan Reddy (1986). Efflux of several enzymes such as creatine phosphokinase (CPK) and LDH has been also reported (Reddy et al.,1971), which is probably due to the alteration in the permeability properties of muscle membrane during physical stress. Thus, possibly owing to the greater metabolic disturbances both GN and SOL muscle fibers seemed to be affected to a greater extent in its phosphorylase system.

A correlation between phosphorylase activity and the rate of glycogen degradation can be envisaged. If the phosphorylase system is active, glycogen utilization will be rapid and the energy supply for the contractile activity is fast. During nicotine intoxication and other stress conditions the phosphorylase activity diminishes with an associated decrease in glycogen degradation which probably results in a decrease in energy supply. Such changes in different muscle fibre types observed to be variable and soleus seemed to be more susceptible to the induced ethanol treatment than the gastrocnemius muscle fibre. Hence, we can conclude that the degree of stress susceptibility in animals is dependent on the fibre types.

\section{CONCLUSION}

This investigation draw a conclusion stating that this much of red grape extracts to the old age as well as young age male subjects may be beneficial, especially for the nicotine subjects to improve the health status and life span. The activities were inhibited in skeletal muscle tissues of rats treated with Nicotine. In conclusion, the present study shows that red grape extracts treatment mitigates nicotine intoxication-induced oxidative damage, which could be due its changes of carbohydrate metabolism nature that combines free radical scavenging and metal chelating properties.

\section{REFERENCES}

1. Maier, T., Schieber, A., Kammerer, D.R and Carle, R.(2009). Residues of grape (Vitis vinifera L.) seed oil production as a valuable source of phenolic antioxidants. Food Chemistry, 112: 551-559.

2. Lafka, T.I., Sinanoglou, V and Lazos, E.S. (2007). On the extraction and antioxidant activity of phenolic compounds from winery waste. Food Chemistry, 104: 1206-1214.

3. Pozo-Bayón, M.A.; Monagas, M.; Bartolome, B and Moreno-Arribas, M.V. (2012).Wine features related to safety and consumer health: An integrated perspective. Crit. Rev. Food Sci. Nutr., 52: 31-54.

4. Arranz, S.; Chiva-Blanch, G.; Valderas-Martínez, P.; Medina-Remón, A.; LamuelaRaventós, R.M and Estruch, R. (2012). Wine, beer, alcohol and polyphenols on cardiovascular disease and cancer. Nutrients, 4: 759-781.

5. Minussi, R.C.; Rossi, M.; Bologna, L.; Cordi, L.; Rotilio, D.; Pastore, G.M. and Durán, N. (2003). Phenolic compounds and total antioxidant potential of commercial wines. Food Chem, 82: 409-416.

6. Pérez-Magariño, S. and González-Sanjosé M.L (2006). Polyphenols and colour variability of red wines made from grapes harvested at different ripeness grade. Food Chem., 96: 197-208.

7. Salas, E.; Fulcrand, H. and Meudec, E. (2003). Cheynier, V. Reactions of anthocyanins and tannins in model solutions. J. Agric. Food Chem., 51: 7951-7961. 
8. Grana, R; Benowitz, Nand Glantz, SA (13 May 2014). "E-cigarettes: a scientificreview." Circulation, 129(19): 1972-86. doi:10.1161/circulationaha. 114.007667. PMC 4018182. PMID 24821826.

9. Holbrook and Bradley D. (2016). "The effects of nicotine on human fetal development". Birth Defects Research Part C: Embryo Today: Reviews., 108(2): 181-92. doi:10.1002/bdrc.21128. ISSN 1542-975X. PMID 27297020.

10. Mayer B (January 2014). "How much nicotine kills a human? Tracing back the generally accepted lethal dose to dubious self-experiments in the nineteenth century". Archives of Toxicology., 88(1): 5-7.

11. Caponnetto, Pasquale; Campagna, Davide; Papale, Gabriella; Russo, Cristina; Polosa and Riccardo (2012)." The emerging phenomenon of electronic cigarettes". Expert Review of Respiratory Medicine. 6(1): 63-74. doi:10.1586/ers.11.92. ISSN 1747- 6348. PMID 22283580.

12. Kozlowski LT, Mehta NY, Sweeney CT, Schwartz SS, Vogler GP, Jarvis MJ and West RJ(1998). Filter ventilation and nicotine content of tobacco in cigarettes from Canada, the United Kingdom and the United States. Tob Control, 7(4): 369-375.

13. Benowitz NL and Jacob P 3rd (1984). Daily intake of nicotine during cigarette smoking. Clin Pharmacol Ther., 35(4): 499-504.

14. Armstrong. DW, Wang. X and Ercal.N,(1998). Enantiomeric composition of nicotine in smokeless tobacco, medicinal prodicts and commercial reagents Chirality, 10: 587-591.

15. Jacob P, 3rd, Yu L, Shulgin AT and Benowitz NL (1999). Minor tobacco alkaloids as biomarkers for tobacco use: comparison of users of cigarettes, smokeless tobacco, cigars and pipes. Am J Public Health, 89(5): 731-736.

16. Leete E(1983). Biosynthesis and metabolism of the tobacco alkaloids. In: Pelletier SW (ed) Alkaloids: chemical and biological perspectives. Wiley, New York, pp 85-152.

17. Tyroller S, Zwickenpflug W and Richter E (2002). New sources of dietary myosmine uptake from cereals, fruits, vegetables, and milk. J Agric Food Chem., 50(17): 49094915.

18. Siegmund B, Leitner E and Pfannhauser W (1999). Determination of the nicotine content of various edible nightshades (Solanaceae) and their products and estimation of the associated dietary nicotine intake. J Agric Food Chem., 47(8): 3113-3120.

19. Harman., D. (1996). Aging and disease: extending functional life span. Ann NYAcad Sci;786:321-336.

20. Harman., D. (1998). Free radicals in Aging. Molec Cell Biochem., 84:155-161.

21. Buettner, G.R. (1993). The packing order of free radicals and antioxidants; lipid peroxidation, alphatocopherol and Ascorbate. ArchBiochem Biophys, 300:535-543.

22. Hausladen, A. and Fridovich, I. (1994). Superoxide and peroxynitrate inactivate aconitases, but nitric does not. J Biol Chem., 269:29405-29408.

23. Carroll, N.V., Longley, R.W., and Roe, J.H. (1956). Glycogen determination in liver and muscle by use of anthrone reagent. J. Biol. Chem., 220: 583-593.

24. Kemp, A., and Van Hejnigen, M.K. (1954). A colorimetric micromethod for the determination of glycogen in tissues. Biochem. J., 56: 646-652.

25. Moore, S., and Stein, W.H. (1954). A modified ninhydrin reagent for the photometric determination of amino acids and released compounds. J.Bio.Chem., 211: 907-913.

26. Cori, G.J., Illingworth, B., and Keller, P.C. (1955). Methods in enzymology. S.P. Colowick and O. Kalpan (eds. Academic Press, New York) 200-204.

27. Lowry, O.H., Rose Brough, N.J., Farr, A.L., and Randall, R.J. (1951). Protein measurement with the folin phenol reagent. J. Biol. Chem., 193: 265-275. 
28. Essen, B., Lindholm, A., and Thomton, J. (1980). Histochemical properties of muscle types and enzyme activities is skeletal muscles of standard bred trotters of different ages. Equine Vet.J., 12: 175-180.

29. Garcia-Estellar, S.C., Robles, S.S., Martin-Requero, A., Ayuso-Parrilla, M.S., and Parrilla, R. (1982). Role of the state of reduction of the DNA system on the regulation of hepatic protein synthesis in the rat in vivo. Int.J.Biochem., 14: 615-620.

30. Idstrom, J.P., Subramanian, V.H., Chance, B., Schersten, T., and Bylund-Fellenius, A.C. (1985). Oxygen dependence of energy metabolism in contracting and recovering rat skeletal muscle. Am.J.Physiol., 248: H 40- H 48.

31. Venkataiah., A. (1995). Effect of exercise training on age-related antioxidant defense mechanisms in rat skeletal muscles. Ph.D. thesis, S.V. University, Tirupati.

32. Tollefsbol., T.O. (1987). Gene expression of carbohydrate metabolism in cellular senescence and aging. Mol. Biol. Med., 4(5): 251-63.

33. Somani, S.m., Buckenmeyer, P., Dube, S.N., Mandalayawala, R.H., Verhulst, S.J., and Knowlton, R.G. (1992). Influence of age and caloric expenditure during exercise. Ind. J. Clin. Pharmacol. Ther. Toxicol., 30 (1): 1-6.

34. Cartee., G.D. (1994). Influence of age on skeletal muscle glucose transport and glycogen metabolism. Med. Sci. Sports. Exerc., 26(5): 577-585.

35. Hughes, V.A., Fiatarone, M.A., Fielding, R.A., Ferrara, C.M., Elahi, D., Evans, W.J. (1995). Long term effects of a high carbohydrate diet and exercise on insulin action in older subjects with impaired glucose tolerance. Am. J. Clin.Nutr., 62(2): 426-33.

36. Dhahbi, J.M., Mote, P.L., Wingo, J., Tillman, J.B., Walford, R.L., and Spindler, S.R. (1999). Calories and aging alter gene expression for gluconeogenic, glycolytic and nitrogen metabolizing enzymes. Am. J. Physiol., 277: E 352-E 360.

37. Holloszy, J.O., and Booth, F.W. (1976). Biochemical adaptations to endurance exercise in muscle. Amm. Rev. Physiol., 38: 273-291.

38. Bilwanath., M.(1996). Biochemical changes in selected parameters of young and old rats to endurance exercise training. M.Phil dissertation, S.V. University, Tirupati (AP), India.

39. Tarnopolsky, M.A., Aktinson, S.A., Phillips, S.M., and Mac Dougall, J.D. (1995). Carbohydrate loading and metabolism during exercise in men and women. Journal of Applied Physiology, 78(4): 1360-1368.

40. Asha Devi, S., and Bhagavathi, R. (1993). Interaction of exercise and age on substrates of carbohydrate metabolism. Ind.J. Expt. Biol. 31: 72-75.

41. Takahashi, A., Philpot, D.E. and Miguel, J. (1970). Electronic Microscopic studies on aging. D. melanogaster. III, Flight Muscle.J.Geront. 25: 228-228.

42. Drahota, Z., and Gutmann, E. (1963). Long term regulatory influences of the nervous system on some metabolic differences in muscles of different function. Physiol. Bohemoslov., 12: 339-348.

43. Ermini, M., and Verzar, F. (1968). Decreased restitution of CP in white and red skeletal muscle during aging. Experientia., 24: 902-904.

44. Frubel Osipova., S.I. (1969). The neuromuscular system In: The basis of gerontology (D.F. Chebotarev, N.V. Malkovskij, and V.V. Frolkis eds), 128-139. Moskva: Meditsina.

45. Ermini., M. (1970). Das Altern der skelett muskulatur. Gerontologia., 16: 231-237.

46. Ermini, M., Szelenyi, F., Moser, P., and Verzar, F. (1971). The aging of skeletal (Straited) muscle by changes of recovery metabolism. Gerontologia.,17: 300-311.

47. Peters. T., Nicolovski. S., Raja. G., Palmer. T.N., and Fournier. P. (1996). Ethanol acutely impairs glycogen repletion in skeletal muscle following high intensity short duration exercise in the rat. Addiction Biology. 7: 289-295. 
48. Vernet, M., Cadefan. J.A., Balague. A., Gran. J.M., Urbano Marquiz. A.V., and Cusso. R. (1995). Effect of chronic alcoholism on human muscle glycogen and glucose metabolism. Alcohol Clin. Exp. Res. 19(5): 1295-9.

49. Van Hom, C.G., and Cunningham, C.C. (1999). Contributions of dietary carbohydrate and ethanol to alterations in liver glycogen levels and glycolytic activity. Alcohol. 19: 139-144.

50. Baio, D.L., Czyz, C.N., Van Hom, C.G. (1998). Effect of chronic ethanol consumption on respiratory and glycolytic activities of rat periportal and perivenous hepatocytes. Archives of Biochemistry and Biophysics. 350: 193-200.

51. Rajendra, W., Indira, K., and Swami, K.S. (1980). Effect of electrical stimulation on ammonia detoxification in amphibian skeletal muscle. Curr.Sci., 49: 681-683.

52. Bhargava., D. (1982). Fatigue induced changes in carbohydrate and protein metabolism and their modulation by pyridoxal-5-phosphate in the gastrocnemius muscle of Bufo melanostictus. Ph.D. thesis, S.V. University, Tirupati (AP), India.

53. Dohm, G.L., Beecher, G.R., Warren, R.Q., and Williams, R.T. (1981). Influence of exercise on free amino acid concentrations in rat tissue. J.Appl.Physiol., 50: 41-44.

54. Krishna Mohan, P., Indira, K. and Rajendra, W. (1985). Protein degradation in functionally different muscles of rat during exhaustive exercise. Indian.J.Exp. Biol. 23: 655-657.

55. Nelson, D.L., and Cox, M.M. (2001). In : Lehninger principles of Biochemistry, $3^{\text {rd }}$ edition, Mac Million Press Ltd., Hampshire, UK. P-873.

56. Bylund-Fellenius, Ann-Christin, Ojamaa, K.M., Flaim, K.E., Li, J.B., Wassner, S.J., and Jefferson, L.S. (1984). Protein synthesis versus energy state in contacting muscles of perfused rat hind limb. Am.J. Physiol., 246: E297-E305.

57. Sahlin, K., Alvestrand, A., Brandt, R., and Hultman, E. (1978). Intra cellular pH and bicarbonate concentration in human muscle during recovery from exercise. J.Appl.Physiol. Respirat Environ. Exercise physiol., 45: 474-480.

58. Krishan Mohan Reddy., P. (1986). Metabolic modulations of fatigue with special reference to lactate and ammonia metabolism in different skeletal muscle fiber types of albino rat. Ph.D. thesis, S.V. University, Tirupati (AP), India.

59. Milakofsky, L., Miller, J.M., and Vogel, W.H. (1986). Effects of acute ethanol administration on rat plasma amino acids and related compounds. Biochem pharmacol. Nov.1; 35(21): 3885-3888.

60. Green, R.S., Mac Dermid, R.G., Scheig, R.1., and Hajjar, J.J. (1981). Effect of ethanol on amino acid absorption across in vivo rat intestine. Am. J. Physiol. Aug; 241 (2): G17681.

61. Chandra Sekharam Naidu., M. (1973). Metabolism of muscular fatigue and associated enzyme kinetics. Ph.D. thesis, S.V. University, Tirupati (AP), India.

62. Reddanna., P. (1979). Some aspects of carbohydrate metabolism in amphibian muscle under the influence of electrical stimulation. Ph.D. thesis, S.V.University. Tirupati (AP), India.

63. Chasiotis, D., Sahlin, K., and Haulman, E. (1982). Regulation of glycogenolysis in human muscle at rest and during exercise. J. Appl. Physiol., 53: 708-715.

64. Chasiotis., D. (1983). The regulation of glycogen phosphorylase and glycogen breakdown in human skeletal muscle. Acta.Physiol. Scand.Suppl., 518: 1-68.

65. Umadevi., L. (1992). Age related metabolic effects of acetaldehyde on rat hepatic and central nervous system with reference to detoxification mechanisms, Ph.D. thesis, Sri Venkateswara University, Tirupati (AP), India.

66. Coggan, Andrew, R., Scott, C., Swanson, Lisa, A., Mendenhall, Diane L. Habash and Lawrence, C. and Kien. (1995). Effect of endurance training on hepatic glycogenolysis 

Physiology., 268: E 375-E 383.

67. Padmavathi, P., Satyanarayana, K., and Swami, K.S. (1975). Intracellular charges and regulation of phosphorylase activity in the gastrocnemius muscle of frog. Curr.Sci., 14: 575-576.

68. Reddy, M.V.V., Kastenchmidt, L.L., Cassens, R.G., and Briskey, E.J. (1971). Studies on stress-susceptibility: The relationship between serum enzyme changes and the degree of stress-susceptibility, Life Sciences, 10: 1381-1391. 